\title{
Front Matter: Volume 6919
}

, "Front Matter: Volume 6919," Proc. SPIE 6919, Medical Imaging 2008: PACS and Imaging Informatics, 691901 (25 March 2008); doi: 10.1117/12.798406

SPIE. Event: Medical Imaging, 2008, San Diego, California, United States 


\title{
PROGRESS IN BIOMEDICAL OPTICS AND IMAGING
}

Vol. 9, No. 36

\section{Medical Imaging 2008}

PACS and Imaging Informatics

\author{
Katherine P. Andriole \\ Khan M. Siddiqui \\ Editors
}

\section{0-21 February 2008 \\ San Diego, California, USA}

Sponsored by

SPIE

Cooperating Organizations

AAPM-American Association of Physicists in Medicine (USA)

APS-American Physiological Society (USA)

CARS - Computer Assisted Radiology and Surgery (Germany)

IS\&T-The Society for Imaging Science and Technology

MIPS-Medical Image Perception Society (USA)

RSNA-Radiological Society of North America (USA)

SIIM-Society for Imaging Informatics in Medicine (USA)

SMI-The Society for Molecular Imaging

The DICOM Standards Committee (USA)

Published by

SPIE

Volume 6919 
The papers included in this volume were part of the technical conference cited on the cover and title page. Papers were selected and subject to review by the editors and conference program committee. Some conference presentations may not be available for publication. The papers published in these proceedings reflect the work and thoughts of the authors and are published herein as submitted. The publisher is not responsible for the validity of the information or for any outcomes resulting from reliance thereon.

Please use the following format to cite material from this book:

Author(s), "Title of Paper," in Medical Imaging 2008: PACS and Imaging Informatics, edited by Katherine P. Andriole, Khan M. Siddiqui, Proceedings of SPIE Vol. 6919 (SPIE, Bellingham, WA, 2008) Article CID Number.

ISSN 1605-7422

ISBN 9780819471031

Published by

SPIE

P.O. Box 10, Bellingham, Washington 98227-0010 USA

Telephone +1 3606763290 (Pacific Time) · Fax +1 3606471445

SPIE.org

Copyright (C) 2008, Society of Photo-Optical Instrumentation Engineers.

Copying of material in this book for internal or personal use, or for the internal or personal use of specific clients, beyond the fair use provisions granted by the U.S. Copyright Law is authorized by SPIE subject to payment of copying fees. The Transactional Reporting Service base fee for this volume is $\$ 18.00$ per article (or portion thereof), which should be paid directly to the Copyright Clearance Center (CCC), 222 Rosewood Drive, Danvers, MA 01923. Payment may also be made electronically through CCC Online at copyright.com. Other copying for republication, resale, advertising or promotion, or any form of systematic or multiple reproduction of any material in this book is prohibited except with permission in writing from the publisher. The CCC fee code is 1605 $7422 / 08 / \$ 18.00$.

Printed in the United States of America.

Publication of record for individual papers is online in the SPIE Digital Library.

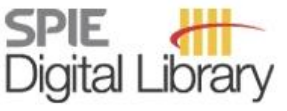

SPIEDigitallibrary.org

Paper Numbering: Proceedings of SPIE follow an e-First publication model, with papers published first online and then in print and on CD-ROM. Papers are published as they are submitted and meet publication criteria. A unique, consistent, permanent citation identifier (CID) number is assigned to each article at the time of the first publication. Utilization of CIDs allows articles to be fully citable as soon they are published online, and connects the same identifier to all online, print, and electronic versions of the publication. SPIE uses a six-digit CID article numbering system in which:

- The first four digits correspond to the SPIE volume number.

- The last two digits indicate publication order within the volume using a Base 36 numbering system employing both numerals and letters. These two-number sets start with 00, 01, 02, 03, 04, $05,06,07,08,09,0 A, 0 B \ldots 0 Z$, followed by 10-1Z, 20-2Z, etc.

The CID number appears on each page of the manuscript. The complete citation is used on the first page, and an abbreviated version on subsequent pages. Numbers in the index correspond to the last two digits of the six-digit CID number. 


\section{Contents}

ix Conference Committee

xi In Memoriam: Sam Dwyer (1932-2008)

SESSION 1 INFRASTRUCTURE AND STANDARDS

691902 How HL7 version 3 is used at the Sahlgrenska University Hospital to exchange information with a central archive [6919-01]

G. Carlsson, T. Hagberg, L. Bogavac, M. Wintell, Sahlgrenska Univ. Hospital (Sweden)

691903 Evaluation of free non-diagnostic DICOM software tools [6919-02]

W. Liao, T. M. Deserno, K. Spitzer, Aachen Univ. of Technology (Germany)

691904 Integrating DICOM structure reporting (SR) into the medical imaging informatics data grid [6919-03]

J. Lee, A. Le, B. Liu, Univ. of Southern California (USA)

691905 A DICOM-RT radiation oncology ePR with decision support utilizing a quantified knowledge base from historical data [6919-04]

J. R. Documet, B. Liu, A. Le, Univ. of Southern California (USA); M. Law, The Hong Kong Polytechnic Univ. (Hong Kong China)

691906 Brokerage mechanism proposal for teleradiology studies distribution [6919-05]

D. Ferreira Polónia, A. F. da Silva, C. M. Costa, J. L. Oliveira, Univ. of Aveiro (Portugal)

\section{SESSION 2 DATABASES AND DATA MINING}

691907 A web-accessible content-based cervicographic image retrieval system [6919-06]

Z. Xue, L. R. Long, S. Antani, National Library of Medicine, NIH (USA); J. Jeronimo, National

Cancer Ctr., NIH (USA); G. R. Thoma, National Library of Medicine, NIH (USA)

691908 Local versus global texture analysis for lung nodule image retrieval (Best Student Paper Award) [6919-08]

R. Datteri, Gonzaga Univ. (USA); D. Raicu, J. Furst, DePaul Univ. (USA)

691909 RadSearch: a RIS/PACS integrated query tool [6919-09]

S. Tsao, J. Documet, P. Moin, K. Wang, B. J. Liu, Keck School of Medicine, Univ. of Southern California (USA)

6919 OA Grid-enabled mammographic auditing and training system [6919-11]

M. H. Yap, A. G. Gale, Applied Vision Research Ctr., Loughborough Univ. (United Kingdom) 


\section{SESSION 3 CLINICAL APPLICATIONS I}

6919 0C A classification framework for lung tissue categorization [6919-13]

A. Depeursinge, J. lavindrasana, A. Hidki, G. Cohen, A. Geissbuhler, A. Platon, P.-A. Poletti, Univ. and Hospitals of Geneva (Switzerland); H. Müller, Univ. and Hospitals of Geneva

(Switzerland) and Univ. of Applied Sciences Sierre (Switzerland)

6919 OD Seeing through the window: pre-fetching strategies for out-of-core image processing algorithms [6919-14]

R. Pinho, K. J. Batenburg, J. Sijbers, Univ. of Antwerp (Belgium)

\section{SESSION 4 CLINICAL APPLICATIONS II}

6919 OE Automated bone age assessment of older children using the radius [6919-15]

S. Tsao, Kent School of Medicine, Univ. of Southern California (USA); A. Gertych, CedarsSinai Medical Ctr. (USA); A. Zhang, B. J. Liu, H. K. Huang, Kent School of Medicine, Univ. of Southern California (USA)

6919 OF Content-based image recognition for digital radiographs [6919-16]

H. Luo, Carestream Health, Inc. (USA); J. Luo, Eastman Kodak Co. (USA)

6919 OG The design and implementation of decision support tools of proton beam therapy treatment planning of brain cancer patients [6919-17]

A. Le, J. Documet, A. Joseph, Univ. of Southern California (USA); R. Schulte, Loma Linda

Univ. Medical Ctr. (USA); B. Liu, Univ. of Southern California (USA)

$6919 \mathrm{OH}$ Web-based computer-aided-diagnosis (CAD) system for bone age assessment (BAA) of children [6919-18]

A. Zhang, J. Uyeda, S. Tsao, K. Ma, Univ. of Southern California (USA); L. A. Vachon, Los Angeles County Women's and Children's Hospital (USA); B. J. Liu, H. K. Huang, Univ. of Southern California (USA)

6919 0l Texture versus shape analysis for lung nodule similarity in computed tomography studies [6919-19]

M. N. Muhammad, Bryn Mawr College (USA); D. S. Raicu, J. D. Furst, E. Varutbangkul, DePaul Univ. (USA)

6919 0J Role of computer aided detection (CAD) integration: case study with meniscal and articular cartilage CAD applications [6919-20]

N. Safdar, Univ. of Maryland School of Medicine (USA); B. Ramakrishna, G. Saiprasad, Univ. of Maryland Baltimore County (USA); K. Siddiqui, VA Maryland Health Care System (USA); E. Siegel, Univ. of Maryland School of Medicine (USA) and VA Maryland Health Care System (USA) 
6919 OK An adaptable XML based approach for scientific data management and integration [6919-21]

F. Wang, Siemens Corporate Research (USA); F. Thiel, Freie Univ. Berlin (Germany); D. Furrer, Swiss Federal Institute of Technology (Switzerland); C. Vergara-Niedermayr, Freie Univ. Berlin (Germany); C. Qin, Peking Univ. (China); G. Hackenberg, RWTH Aachen Univ. (Germany); P.-E. Bourgue, LogicaCMG (France); D. Kaltschmidt, Freie Univ. Berlin (Germany); M. Wang, Univ. of Duisburg-Essen (Germany)

$6919 \mathrm{OL}$ Design and implementation of GRID-based PACS in a hospital with multiple imaging departments [6919-22]

Y. Yang, J. Jin, J. Sun, J. Zhang, Shanghai Institute of Technical Physics (China)

6919 OM Implementation and use of a web-based interface for confidential communication of data between the clinical and research environments [6919-23]

P. H. Bland, G. E. Laderach, C. R. Meyer, Univ. of Michigan Health System (USA)

6919 ON Performance benchmarking of liver CT image segmentation and volume estimation [6919-24]

W. Xiong, Institute for Infocomm Research, A*STAR (Singapore); J. Zhou, National Univ. of Singapore (Singapore); Q. Tian, J. J. Liu, Institute for Infocomm Research, A*STAR (Singapore); Y. Qi, W. K. Leow, National Univ. of Singapore (Singapore); T. Han, S. Wang, National Univ. of Singapore (Singapore)

691900 Assuring image authenticity within a data grid using lossless digital signature embedding and a HIPAA-compliant auditing system [6919-25]

J. C. Lee, K. C. Ma, B. J. Liu, Keck School of Medicine, Univ. of Southern California (USA)

SESSION 6 DISPLAYS, VISUALIZATION, INTERPRETATION

6919 OP Improved display calibration algorithm for wide viewing angle DICOM GSDF compliance [6919-26]

T. Kimpe, C. Marchessoux, Barco - Medical Imaging Div. (Belgium)

$69190 Q \quad$ Display methods for adjustable grayscale and luminance depth [6919-27]

A. XU, A. Saha, Ctr. for Devices and Radiological Health, U.S. FDA (USA); G. Guarnieri, Univ. of Trieste (Italy) and FIMI/Philips (Italy); G. Ramponi, Univ. of Trieste (Italy); A. Badano, Ctr. for Devices and Radiological Health, U.S. FDA (USA)

6919 OR The effect of increased ambient lighting on detection accuracy in uniform and anatomical backgrounds [6919-28]

B. J. Pollard, A. S. Chawla, Duke Advanced Imaging Labs. (USA) and Duke Univ. (USA); N. Hashimoto, Eizo Nanao Technologies, Inc. (USA) and Duke Advanced Imaging Labs. (USA); E. Samei, Duke Advanced Imaging Labs. (USA) and Duke Univ. (USA)

6919 OS Rapid prototyping of clinical software assistants [6919-29]

J. Rexilius, H.-O. Peitgen, MeVis Research (Germany) 
6919 OT ImTK: an open source multi-center information management toolkit [6919-30] A. Alaoui, M. L. Ingeholm, S. Padh, M. Dorobantu, M. Desai, K. Cleary, S. K. Mun, Georgetown Univ. (USA)

6919 OU The workflow and procedures for automatic integration of a computer-aided diagnosis workstation with a clinical PACS with real world examples [6919-31]

A. Le, L. Mai, B. Liu, H. K. Huang, Univ. of Southern California (USA)

SESSION 7 SURGICAL PACS

6919 OV Integration of implant planning workflows into the PACS infrastructure [6919-32] M. Gessat, Univ. of Leipzig (Germany); G. StrauB, Univ. of Leipzig (Germany) and Univ. Hospital Leipzig (Germany); O. Burgert, Univ. of Leipzig (Germany)

6919 OW A general framework for data streaming in the digital operating room [6919-33] R. Mayoral, A. Vázquez, O. Burgert, Innovation Ctr. Computer Assisted Surgery (Germany)

6919 0X Automatic real-time capture and segmentation of endoscopy video [6919-34] S. R. Stanek, W. Tavanapong, J. S. Wong, lowa State Univ. (USA); J. Oh, Univ. of North Texas (USA); P. C. de Groen, Mayo Clinic (USA)

6919 OY Workflow in interventional radiology: uterine fibroid embolization (UFE) [6919-35] D. Lindisch, Georgetown Univ. (USA); T. Neumuth, O. Burgert, Univ. of Leipzig (Germany); J. Spies, K. Cleary, Georgetown Univ. (USA)

$69190 Z$ Integration of a real-time video grabber component with the open source image-guided surgery toolkit IGSTK [6919-36]

O. V. Solberg, SINTEF Health Research (Norway), National Ctr. for 3D Ultrasound in Surgery (Norway), and Norwegian Univ. of Science and Technology (Norway); G.-A. Tangen,

F. Lindseth, T. Sandnes, SINTEF Health Research (Norway) and National Ctr. for 3D Ultrasound in Surgery (Norway); A. A. Enquobahrie, L. Ibáñez, Kitware, Inc. (USA); P. Cheng, Imaging Science and Information Systems Ctr. (USA); D. Gobbi, Atamai, Inc. (Canada) and Queen's Univ. (Canada); K. Cleary, Imaging Science and Information Systems Ctr. (USA)

\section{POSTER SESSION}

691910 Content based image retrieval applied to contrast enhancing brain tumors [6919-10] H. Z. Tameem, S. Dube, Univ. of California, Los Angeles (USA); U. Sinha, Univ. of California, Los Angeles (USA) and San Diego State Univ. (USA)

691911 A novel multidimensional medical image display framework based on visualization toolkit [6919-37]

J. Shuai, J. Sun, J. Zhang, Shanghai Institute of Technical Physics (China)

691912 A novel strategy to access high resolution DICOM medical images based on JPEG2000 interactive protocol [6919-38]

Y. Tian, W. Cai, J. Sun, J. Zhang, Shanghai Institute of Technical Physics (China) 
691913 Database construction for small lung nodule using high-resolution three-dimension CT image [6919-41]

Y. Kozaki, Y. Kawata, N. Niki, The Univ. of Tokushima (Japan); H. Ohmatsu, National Cancer Ctr. Hospital East (Japan); M. Kusumoto, National Cancer Ctr. Hospital (Japan);

R. Kakinuma, National Cancer Ctr. (Japan); K. Eguchi, Univ. of Teikyo (Japan); M. Kaneko, National Cancer Ctr. Hospital (Japan); N. Moriyama, National Cancer Ctr. (Japan)

691914 Integration of a research CBIR system with RIS and PACS for radiological routine (Honorable Mention Poster Award) [6919-42]

B. Fischer, T. M. Deserno, B. Ott, R. W. Günther, RWTH Aachen Univ. of Technology (Germany)

691915 Development of a mobile HIS/PACS workstation to assist critical cardiac patients in an intensive care unit [6919-43]

M. A. Gutierrez, I. A. Cestari, G. Hamamoto, S. Bacht, M. S. Rebelo, J. E. M. M. Silva,

S. G. Lage, Univ. of São Paulo Medical School (Brazil)

691916 Computer-aided diagnosis workstation and network system for chest diagnosis based on multislice CT images (Cum Laude Poster Award) [6919-44]

H. Satoh, Tokyo Healthcare Univ. (Japan); N. Niki, Univ. of Tokushima (Japan); K. Eguchi, School of Medicine, Tokai Univ. (Japan); N. Moriyama, National Cancer Ctr. Hospital (Japan); H. Ohmatsu, National Cancer Ctr. Hospital East (Japan); H. Masuda, S. Machida, Tochigi Public Health Service Association (Japan)

691917 Using eclipse RCP for the contextual image viewer [6919-45]

R. A. Moreno, S. S. Furuie, Hospital das Clínicas da Faculdade de Medicina da Univ. de São Paulo (Brazil)

691918 Bone age assessment in Hispanic children: digital hand atlas compared with the Greulich and Pyle (G\&P) atlas [6919-46]

J. R. Fernandez, A. Zhang, L. Vachon, S. Tsao, Univ. of Southern California (USA)

Author Index 
Proc. of SPIE Vol. $6919691901-8$

Downloaded From: https://www.spiedigitallibrary.org/conference-proceedings-of-spie on 26 Apr 2023 Terms of Use: https://www.spiedigitallibrary.org/terms-of-use 


\title{
Conference Committee
}

\author{
Symposium Chairs
}

Milan Sonka, The University of lowa (USA)

Armando Manduca, Mayo Clinic (USA)

Conference Chairs

Katherine P. Andriole, Brigham \& Women's Hospital/Harvard Medical School (USA)

Khan M. Siddiqui, VA Maryland Health Care System (USA)

Program Committee

William W. Boonn, University of Pennsylvania (USA)

Kevin R. Cleary, Georgetown University (USA)

Janice C. Honeyman-Buck, University of Florida (USA)

Steven C. Horii, University of Pennsylvania (USA)

Heinz U. Lemke, Computer Assisted Radiology and Surgery (Germany)

Brent J. Liu, University of Southern California (USA)

John B. Strauss, FUJIFILM Medical Systems USA, Inc. (USA)

Wyatt Tellis, University of California, San Francisco (USA)

\section{Session Chairs}

1 Infrastructure and Standards

Brent J. Liu, University of Southern California (USA)

2 Databases and Data Mining

Wyatt Tellis, University of California, San Francisco (USA)

3 Clinical Applications I

Katherine P. Andriole, Brigham \& Women's Hospital/Harvard Medical School (USA)

4 Clinical Applications II

Khan M. Siddiqui, VA Maryland Health Care System (USA)

$5 \quad$ Systems Integration and Infrastructure

Janice C. Honeyman-Buck, University of Florida (USA)

6 Displays, Visualization, Interpretation

William W. Boonn, University of Pennsylvania (USA)

7 Surgical PACS

Heinz U. Lemke, Computer Assisted Radiology and Surgery (Germany) 
Proc. of SPIE Vol. 6919 691901-10

Downloaded From: https://www.spiedigitallibrary.org/conference-proceedings-of-spie on 26 Apr 2023 Terms of Use: https://www.spiedigitallibrary.org/terms-of-use 


\section{In Memoriam}

\section{Sam Dwyer}

1932-2008

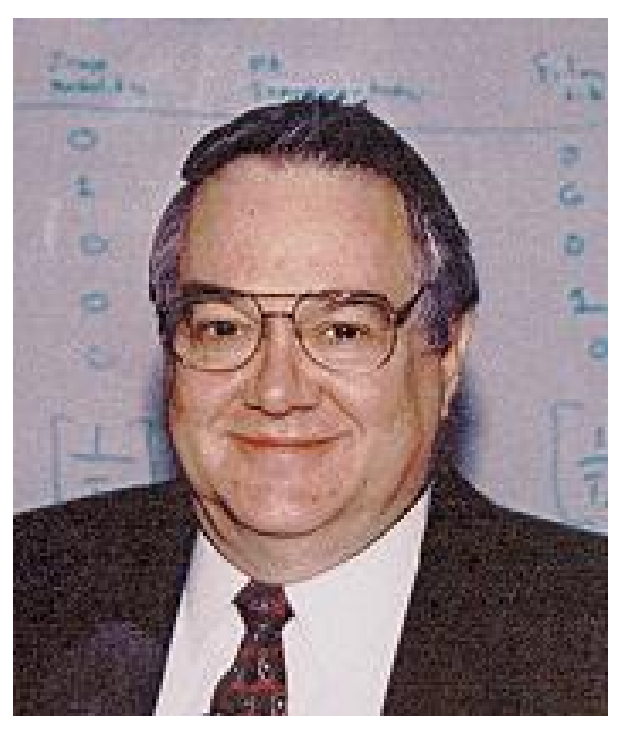

\section{Inspirational planner for SPIE Medical Imaging symposia and chair of 15 conferences from 1983 to 1996}

Sam Dwyer was a leading light in the swift growth of the field of medical imaging. At this 2008 Medical Imaging symposium, several colleagues expressed their appreciation of his professional achievements and the legacy of his contributions.

Andre Duerinckx recalls Sam's first big step into the limelight. "Sam chaired the Second International PACS meeting sponsored by SPIE in 1983. He stepped in when my professional direction shifted and I could not continue. Over the following years Sam became a leading force in the development of this new science and technology as the conferences developed and grew."

"He had an ability to predict important technology trends in medical imaging," says Steven Horii, a long-time SPIE Medical Imaging contributor and past conference chair.

Another past Medical Imaging conference chair with years of experience, Roger Schneider elaborates, "The growth of the initial conferences was phenomenal. They quickly expanded and outgrew several facilities. Topic areas increased. For example, we had been dealing with perception in sessions on image statistics. Sam first suggested that the field of perception theory and experiment was expanding so rapidly that it deserved its own conference. We also added conferences on image processing hardware, display, functional imaging, and special topics in ultrasound transducers."

"Sam was a true pioneer in our field," continues Schneider. "He was one of the first to envision the impact of digital technology on the storage, retrieval, communication, and 
display of medical images, and one of the most active early explorers of the possibilities. He led the PACS conference into the merger with SPIE's image science conference to form the current Medical Imaging Symposium which many consider to be the premiere technical program on medical imaging in the world."

Murray Loew, another past conference chair, adds his observation, "Sam's academic, industrial, and clinical experience provided the perspective that enabled him to set priorities and give advice that helped many of us to make our own contributions. We all benefited greatly from his insights and his practical approach."

Schneider agrees. "Through all, Sam was an excellent partner and leader, calm, gentle yet persuasive, always congenially nudging everyone toward a better future. His ambitions were not for himself, but for the mutual enterprise. He was a very enthusiastic mentor and supporter of students and researchers new to the field without any concern for the possibility that their work might compete with his and was himself a superbly competent contributor."

An example of this is illustrated by John Strauss." Already well accomplished at the time of our first meeting, Sam made the time to take an eager but inexperienced student under his wing. I was not an 'assigned' grad student or research assistant from the University to which he had an obligation. I was a product manager from a vendorpartner. Over the years, from answering technical questions in an understandable way, to providing unassuming career guidance, as well as a sympathetic ear to the challenges of fatherhood or life's many challenges and struggles, Sam was always there for me."

"There are many things about Sam Dwyer that I recall with great fondness, like his always friendly and enthusiastic manner. His advice led me to my years of satisfying work on the ACR-NEMA Committee," adds Horii.

All agree that Sam had many other admirable traits. His wit and sense of humor were legendary, as one of Schneider's favorite memories illustrates. "At the opening of one conference Sam announced, from the podium, that it was the birthday of an important attendee. He said SPIE had requested that the Blue Angels do a flyover-but they already had something scheduled. As a substitute birthday recognition, Sam suggested we take our morning coffee break out on the terrace and watch the landscaping crew circle the flagpole on their riding lawnmowers."

Strauss describes the footprint left by Sam, "While Sam left a legacy through his professional accomplishments, perhaps more lasting is the heritage of leadership he has left behind. He felt it his obligation to pass on his knowledge and wisdom to the next generation, and I was blessed as a recipient. I have and will continue to honor Sam by sharing with those that come after me."

Sam Dwyer was a person of rare quality who will be sorely missed. His name has a permanent place in the annals of medical imaging, and his contributions continue in the flourishing growth of knowledge presented and discussed in the annual Medical Imaging conferences. 